\title{
PERTUMBUHAN B IBIT KELAPA SAWIT DENGAN APLIKASI ASAP CAIR LIMBAH PELEPAH KELAPA SAWIT
}

\author{
(Growth Of Palm Oil Seeds With Application Of Liquid Smoke From \\ Palm Oil Midrib-Leaf Waste)
}

\author{
Mila Lukmana, Diah Karunia, Zuliyan Agus Nur Muchlis Majid \\ Program Studi Budidaya Tanaman Perkebunan, Politeknik Hasnur \\ Jl. Brigjend. H. Hasan Basri, Handil Bakti Ray V, Barito Kuala 70582 \\ Penulis Koresponden: milalukmana@gmail.com
}

Article Submitted : 30-12-2021

Article Accepted : 21-01-2022

\begin{abstract}
The growth of good and quality seeds requires a lot of fertilization, considering that oil palm seeds grow quickly. Generally, the fertilizers used are compound fertilizers and inorganic single fertilizers. Continuous use of inorganic fertilizers without being balanced by organic fertilizers can reduce soil quality. Therefore, alternative fertilizers are needed to reduce the use of inorganic fertilizers. Liquid smoke from palm oil midrib-leaf waste can be developed into organic fertilizer, so a lot of studies are needed. This study aims to determine the growth of oil palm seedlings by giving liquid smoke from palm oil midrib-leaf waste. The treatments given were P0 (0\% /control), P1 (2\% liquid smoke), P2 (3\% liquid smoke), P3 (4\% liquid smoke), P4 (5\% liquid smoke), P5 (10\% liquid smoke ), P6 (15\% liquid smoke) and P7 (20\% liquid smoke). The results obtained are analyzed. A further BNJ test will be carried out at the $5 \%$ level if they give significantly different results. Parameters observed were plant height $(\mathrm{cm})$, number of leaves (strands), leaf area ( $\mathrm{cm} 2)$, and diameter of stem circumference $(\mathrm{mm})$. The application of liquid smoke from the palm fronds had a significant effect on plant height and leaf area of oil palm seedlings, while the parameters of the quantity leaves and stem diameter had no significant effect. The best treatment based on plant height and leaf area parameters was $2 \%$ liquid smoke from palm oil midrib-leaf.
\end{abstract}

Keywords: liquid smoke, palm oil midrib-leaf, palm oil

\section{PENDAHULUAN}

Budidaya tanaman kelapa sawit diawali dengan proses pembibitan. Pembibitan kelapa sawit bila dikelola dengan baik akan menghasilkan bibit yang sehat dan berpengaruh terhadap pertumbuhannya di lapangan (Lubis \& Sjofjan, 2016). Pada tahapan pembibitan, tanaman kelapa sawit memerlukan media dengan kandungan unsur hara yang tinggi. Unsur hara didapatkan selain dari media juga perlu ditambahkan pupuk. Pupuk tanaman dibagi dengan beberapa kriteria seperti pupuk anorganik majemuk, pupuk organik tunggal, dan pupuk organik. Terdapat beberapa kendala dalam pemberian pupuk anorganik diantaranya karena biaya yang dikeluarkan lebih tinggi dan penggunaan pupuk secara terus menerus dapat merusak lingkungan serta menurunkan kualitas dan produktivitas tanah. Oleh sebab itu diperlukan pupuk alternatif untuk mengurangi pemakaian pupuk anorganik salah satunya dengan pengaplikasian bahan organik. 
Salah satu bahan organik yang memiliki ketersediaan tinggi adalah pelepah kelapa sawit. Untuk memudahkan proses pemanenan dan penyerbukan, pelepah kelapa sawit harus dipotong. Pelepah kelapa sawit mengandung selulosa 34,89\%, hemiselulosa 27,14\%, dan lignin 19,87\%, serta zat- zat ekstraktif. (Maulina, dkk 2018). Akan tetapi, tanaman tidak dapat menyerap bahan organik kompleks sehingga diperlukan proses degradasi (Maulina dkk, 2018).

Limbah padat perkebunan dan industri kelapa sawit mengandung bahan organik tinggi yang berpotensi mencemari lingkungan jika tidak dilakukan penanganan secara tepat. Menurut Haji (2013) limbah padat kelapa sawit mengandung hemiselulosa, selulosa, lignin, abu serta komponen lain. Berdasarkan komponen tersebut maka penanganan limbah dengan cara penumpukan dan pembakaran bukan metode yang tepat dan efektif. Salah satu teknologi alternatif dalam pengolahan limbah padat kelapa sawit yaitu melalui Teknik Pirolisis. Menurut Haji (2013), teknik ini dapat mengolah limbah padat kelapa sawit secara cepat. Melalui teknik pirolisis dari biomassa dapat menghasilkan arang dan asap (Fauziati \& Haspiadi, 2016).Asap yang dikeluarkan terkondensasi menjadi kondensat yang disebut asap cair .

Dibidang pertanian, asap cair digunakan untuk mendukung pertumbuhan tanaman, pengendalian organisme pengganggu tumbuhan (OPT), pengawet alami, dan koagulan lateks. Penelitian Lubis dkk (2014) diketahui bahwa penggunaan asap cair tandan kosong kelapa sawit mempengaruhi tinggi tanaman dan massa kelapa sawit, dengan dosis asap cair TKKS terbaik $150 \mathrm{ml} /$ polybag. Gusmailina et al., (2018), melaporkan bahwa asap cair kayu sengon dan kayu karet sebesar $4 \%$ memberikan hasil terbaik dalam meningkatkan pertumbuhan anakan Gyrinops sp. Istiqomah \& Kusumawati, (2020) telah menguji penggunaan asap cair sekam pada tanaman padi. Hasilnya diketahui bahwa asap cair sekam sebesar $2 \%$ pertumbuhan dan produksi padi meningkat. Peningkatan produksi padi meliputi tinggi padi, jumlah gabah per malai, jumlah anakan, dan berat bulir padi. Penelitian lain dilakukan Sari et al., (2020) diketahui bahwa pengaplikasian kitosan asap cair 7,5\% dan $10 \%$ berpengaruh signifikan pada pertumbuhan dan perkembangan tanaman cabai rawit merah. Sehingga tujuan dari penelitian ini adalah untuk pengaruh aplikasi asap cair limbah pelepah sawit terhadap pertumbuhan bibit kelapa sawit (mainnursery). Diharapkan dengan adanya penelitian ini dapat menjadi alternatif atau mengurangi penggunaan pupuk anorganik dalam pembibitan kelapa sawit, melindungi bibit kelapa sawit dari serangan OPT sekaligus mengurangi penumpukan limbah padat khususnya pelepah kelapa sawit di perkebunan.

\section{METODE PENELITIAN}

Penelitian ini dilaksanakan di Laboratorium dan Green House Program Studi Budidaya Tanaman Perkebunan, Politeknik Hasnur selama 6 bulan. Alat yang digunakan adalah pirolisator, hand sprayer, penggaris, jangka sorong, gelas ukur, timbangan, dan cangkul. Bahan yang digunakan yaitu pelepah kelapa sawit, bibit kelapa sawit Marihat berumur 3 bulan, kertas saring, kertas Whatmann 42, polybag, air dan topsoil. Pembuatan asap cair limbah pelepah kelapa sawit menggunakan pirolisator pada suhu sekitar $200{ }^{\circ} \mathrm{C}$. Kemudian asap cair diendapkan selama 24 jam agar terbentuk 2 lapisan. Lapisan atas diambil kemudian disaring menggunakan kertas saring sebanyak 2 kali dan kertas Whatmann 42 sebanyak 1 kali. Asap cair tersebut dilarutkan dengan air sesuai perlakuan yang akan diberikan.

Pengaplikasian asap cair dilakukan pada bibit kelapa sawit berumur 3 bulan. Perlakuan diberikan interval 7 hari sekali, dengan cara menyemprotkan asap cair 
menggunakan hand sprayer pada pagi hari. Gulma dibersihkan setiap hari dan tanaman disiram dua kali setiap hari. Desain percobaan menggunakan Rancangan Acak Lengkap (RAL). Perlakuan asap cair pelepah kelapa sawit yang diberikan sebagai berikut: P0 (0\% /Kontrol), P1 (2\% asap cair), P2 (3\% asap cair), P3 (4\% asap cair), P4 (5\% asap cair), P5 (10\% asap cair), P6 (15\% asap cair) dan P7 (20\% asap cair). Hasil yang diperoleh dianalisa, apabila memberikan hasil berbeda nyata akan dilakukan uji lanjutan BNJ dengan taraf dignifikasi 5\%. Parameter yang diamati adalah jumlah daun, luas daun, tinggi tanaman, dan diameter lingkar batang. Pengamatan tinggi tanaman, jumlah daun dan luas daun dilakukan sejak kelapa sawit berumur 3 bulan (masuk tahap mainnursery) dengan interval pengamatan setiap 7 hari sekali, sedangkan diameter lingkar batang dengan interval pengamatan setiap 30 hari sekali.

\section{HASIL DAN PEMBAHASAN}

\section{Tinggi Tanaman}

Aplikasi asap cair pelepah kelapa sawit pada tahap main-nursery kelapa sawit

Tabel 1. Hasil tinggi bibit kelapa sawit (cm) menunjukan hasil tinggi tanaman yang ditunjukkan pada Tabel 1. Perlakuan asap cair pelepah kelapa sawit dengan konsentrasi $2 \%, 3 \%, 4 \%, 5 \%$ dan $10 \%$ pada parameter tinggi tanaman berbeda signifikan dibandingkan kontrol (tanpa perlakuan asap cair). Namun, antar perlakuan P1 (2\% asap cair), P2 (3\% asap cair), P3 (4\% asap cair), P4 (5\% asap cair) dan P5 (10\% asap cair) memberikan hasil perbedaan yang tidak signifikan terhadap tinggi bibit kelapa sawit. Pada peningkatan konsentrasi asap cair pelepah kelapa sawit P6 (15\% asap cair) dan P7 $(20 \%$ asap cair) menunjukkan pertumbuhan tinggi bibit kelapa sawit cenderung lambat dan menunjukkan perbedaan secara signifikan dengan kontrol. Hasil tersebut menunjukan bahwa tanaman memiliki batas serapan hara sehingga pemberian hara yang melebihi atau kurang dari kebutuhannya akan menghambat pertumbuhan. Menurut Gunawan et al., (2019) pemberian pupuk berlebih justru dapat menghambat pertumbuhan tanaman akibat cekaman unsur hara sehingga dipelukan dosis yang tepat dalam pemupukan.

\begin{tabular}{ccccc}
\hline \multirow{2}{*}{ Perlakuan } & \multicolumn{4}{c}{ Waktu Pengamatan (MST) } \\
\cline { 2 - 5 } & 2 & 4 & 6 & 8 \\
\hline P0 & $24,5^{\mathrm{a}}$ & $26,2^{\mathrm{a}}$ & $27,8^{\mathrm{a}}$ & $29^{\mathrm{a}}$ \\
P1 & $32^{\mathrm{b}}$ & $33,7^{\mathrm{b}}$ & $34,9^{\mathrm{b}}$ & $36,2^{\mathrm{b}}$ \\
P2 & $31,3^{\mathrm{b}}$ & $33,4^{\mathrm{b}}$ & $34,9^{\mathrm{b}}$ & $36,3^{\mathrm{b}}$ \\
P3 & $30,7^{\mathrm{b}}$ & $33,9^{\mathrm{b}}$ & $35,8^{\mathrm{b}}$ & $37,6^{\mathrm{b}}$ \\
P4 & $31,1^{\mathrm{b}}$ & $33,6^{\mathrm{b}}$ & $35,3^{\mathrm{b}}$ & $37,3^{\mathrm{b}}$ \\
P5 & $32,1^{\mathrm{b}}$ & $33,3^{\mathrm{b}}$ & $34,5^{\mathrm{b}}$ & $35,8^{\mathrm{b}}$ \\
P6 & $24^{\mathrm{a}}$ & $25,6^{\mathrm{a}}$ & $26,6^{\mathrm{a}}$ & $27,9^{\mathrm{a}}$ \\
P7 & $23,4^{\mathrm{a}}$ & $24,6^{\mathrm{a}}$ & $25,5^{\mathrm{a}}$ & $26,9^{\mathrm{a}}$ \\
\hline
\end{tabular}

Keterangan: angka pada kolom yang sama diikuti huruf yang sama tidak berbeda nyata merurut uji BNJ 5\%

Standar pertumbuhan tinggi kelapa sawit dura $\mathrm{x}$ pesifera normal berumur 5 bulan yaitu $32 \mathrm{~cm}$ (Lubis , 2008 dalam
Tobing, 2018). Pada penelitian ini tinggi bibit kelapa sawit dengan perlakuan asap cair konsentrasi 2\%, 3\%, 4\%, 5\% dan $10 \%$ 
berkisar antara 35,8 - 37,6 $\mathrm{cm}$ telah memenuhi standar pertumbuhan tinggi bibit kelapa sawit normal berumur 5 bulan.

Asap cair pelepah kelapa sawit mengandung asam asetat, Ca-Mineral, COrganik, N-Urea dan P-Phospat (Rustam et al., 2012). Kandungan hara tersebut dibutuhkan bagi pertumbuhan tanaman. Tanaman memerlukan sejumlah unsur hara baik makro dan mikro untuk pertumbuhannya. Shaila et al., (2019) menyatakan hara digunakan tanaman dalam proses fotosintesis untuk menghasilkan fotosintat. Fotosintat tersebut dipergunakan tanaman sebagai energi untuk pertumbuhan vegetatif seperti daun dan tinggi tanaman.

Unsur tanaman yang berperan dalam meningkatkan tinggi tanaman diantaranya nitrogen $(\mathrm{N})$ dan fosfor $(\mathrm{P})$. Unsur $\mathrm{N}, \mathrm{P}, \mathrm{K}$ dibutuhkan untuk pertumbuhan kelapa sawit (Sudradjat \& Siagian, 2014) dan unsur tersebut merupakan hara primer sebab dapat menjadi faktor pembatas pertumbuhan tanaman (Sudradjat, Darwis, Fauziah, et al., 2015). Nitrogen diperlukan tanaman sebagai penyusun protein, asam amino, asam nukleat, nukleotida dan klorofil (IFA, 2007 dalam Sudradjat et al., 2015). Unsur nitrogen berperan dalam pertumbuhan tanaman untuk membentuk struktur batang dan daun (Pamungkas \& Supijatno, 2017). Kekurangan nitrogen menyebabkan pertumbuhan tanaman menjadi terhambat dan kerdil (Sudradjat, Darwis, Fauziah, et al., 2015).

\section{Jumlah Daun}

Pengamatan parameter jumlah daun bibit kelapa sawit ditunjukkan pada Tabel 2 . Berdasarkan Tabel 2 diketahui bahwa semua perlakuan asap cair memberikan hasil perbedaan yang tidak signifikan dengan kontrol (tanpa pemberian asap cair) pada parameter jumlah daun.

Tabel 2.Hasil jumlah daun bibit kelapa sawit (helai)

\begin{tabular}{ccccc}
\hline \multirow{2}{*}{ Perlakuan } & \multicolumn{4}{c}{ Waktu Pengamatan $($ MST) } \\
\cline { 2 - 5 } & 2 & 4 & 6 & 8 \\
\hline P0 & $3^{\mathrm{a}}$ & $3,3^{\mathrm{a}}$ & $3,7^{\mathrm{a}}$ & $4,3^{\mathrm{a}}$ \\
P1 & $3^{\mathrm{a}}$ & $3,7^{\mathrm{a}}$ & $4^{\mathrm{a}}$ & $4,3^{\mathrm{a}}$ \\
P2 & $3^{\mathrm{a}}$ & $3,7^{\mathrm{a}}$ & $4^{\mathrm{a}}$ & $5^{\mathrm{a}}$ \\
P3 & $3^{\mathrm{a}}$ & $3,3^{\mathrm{a}}$ & $3,7^{\mathrm{a}}$ & $5^{\mathrm{a}}$ \\
P4 & $3^{\mathrm{a}}$ & $3,3^{\mathrm{a}}$ & $3,3^{\mathrm{a}}$ & $4,3^{\mathrm{a}}$ \\
P5 & $3,3^{\mathrm{a}}$ & $3,7^{\mathrm{a}}$ & $3,7^{\mathrm{a}}$ & $4,7^{\mathrm{a}}$ \\
P6 & $2^{\mathrm{a}}$ & $3^{\mathrm{a}}$ & $3,7^{\mathrm{a}}$ & $3,7^{\mathrm{a}}$ \\
P7 & $3^{\mathrm{a}}$ & $3^{\mathrm{a}}$ & $3,3^{\mathrm{a}}$ & $3,7^{\mathrm{a}}$ \\
\hline
\end{tabular}

Keterangan: angka pada kolom yang sama diikuti huruf yang sama tidak berbeda nyata merurut uji BNJ 5\%

Standar pertumbuhan daun pada bibit kelapa sawit Dura x Pesifera normal umur 5 bulan adalah 5,5 helai (Lubis, 2008 dalam Tobing, 2018). Pada penelitian ini, perlakuan asap cair pelepah kelapa sawit menghasilkan jumlah daun berkisar 3,7 - 5 helai yang belum memenuhi standar jumlah daun pada bibit kelapa sawit berumur 5 bulan. Hal ini disebabkan unsur nitrogen yang terkandung dalam asap cair pelepah kelapa sawit belum mencukupi untuk mendukung pertumbuhan daun baru. Selain itu disebabkan karena pada asap cair pelepah kelapa sawit tidak mengandung hara kalium yang juga berperan dalam pembentukan daun. Mengingat selama penelitian tidak diberikan pupuk tambahan selain perlakuan asap cair pelepah kelapa sawit. Menurut Rustam et al., (2012) asap cair pelepah kelapa sawit mengandung asam asetat, $\mathrm{Ca}$ - 
Mineral, C-Organik, N-Urea dan P-Phospat. Shintarika et al., (2016) melaporkan bahwa pemupukan nitrogen dikombinasikan dengan fosfor tidak berpengaruh terhadap jumlah pelepah daun. Pemberian pupuk nitrogen dikombinasikan kalium pada bibit kelapa sawit mampu meningkatkan jumlah pelepah sebesar 4,8\% (Halim et al., 2014).

Tabel 3. Hasil luas daun bibit kelapa sawit $\left(\mathrm{cm}^{2)}\right.$

\section{Luas daun}

Tabel 3 menunjukkan hasil analisa parameter luas daun. Pada perlakuan pemberian asap cair P1(2\%), P2 (3\%), P3 (4\%), P4 (5\%) dan P5 (10\%) memberikan hasil berpengaruh nyata pada paremeter luas daun dibandingkan kontrol (tanpa pemberian asap cair). Akan tetapi antar perlakuan P1, P2, P3, P4 dan P5 menunjukkan hasil perbedaan yang tidak signifikan.

\begin{tabular}{ccccc}
\hline \multirow{2}{*}{ Perlakuan } & \multicolumn{4}{c}{ Waktu Pengamatan (MST) } \\
\cline { 2 - 5 } & 2 & 4 & 6 & 8 \\
\hline P0 & $60,3^{\mathrm{a}}$ & $68,2^{\mathrm{a}}$ & $76,8^{\mathrm{a}}$ & $86,7^{\mathrm{a}}$ \\
P1 & $98,2^{\mathrm{b}}$ & $105,9^{\mathrm{b}}$ & $113,7^{\mathrm{b}}$ & $121,6^{\mathrm{b}}$ \\
P2 & $97,3^{\mathrm{b}}$ & $107,4^{\mathrm{b}}$ & $117,7^{\mathrm{b}}$ & $127,2^{\mathrm{b}}$ \\
P3 & $89,6^{\mathrm{b}}$ & $103,1^{\mathrm{b}}$ & $116,5^{\mathrm{b}}$ & $128,3^{\mathrm{b}}$ \\
P4 & $73,9^{\mathrm{b}}$ & $85^{\mathrm{b}}$ & $96^{\mathrm{b}}$ & $106,9^{\mathrm{b}}$ \\
P5 & $73,9^{\mathrm{b}}$ & $95^{\mathrm{b}}$ & $112,7^{\mathrm{b}}$ & $130,1^{\mathrm{b}}$ \\
P6 & $56,3^{\mathrm{a}}$ & $63,4^{\mathrm{a}}$ & $70,3^{\mathrm{a}}$ & $77,1^{\mathrm{a}}$ \\
P7 & $43,8^{\mathrm{a}}$ & $49^{\mathrm{a}}$ & $59^{\mathrm{a}}$ & $67,5^{\mathrm{a}}$ \\
\hline
\end{tabular}

Keterangan: angka pada kolom yang sama diikuti huruf yang sama tidak berbeda nyata merurut uji BNJ 5\%

Berdasarkan uji BNJ 5\%, peningkatan dosis asap cair pelepah kelapa sawit pada perlakuan P6 (15\%) dan P7 (20\%) menghasilkan perbedaan hasil luas daun yang tidak signifikan dengan kontrol (tanpa pemberian asap cair). Hal tersebut diduga, konsentrasi asap cair yang diberikan berlebihan bagi bibit kelapa sawit sehingga menekan laju pertumbuhan yang terlihat dari parameter luas daun cenderung rendah. Satria et al., (2015) melaporkan perlakuan dosis tertinggi dengan kompos TKKS 2/3 bagian dari media dan pupuk NPK dengan dosis $3 \mathrm{~g} /$ tanaman menghasilkan tinggi tanaman, jumlah daun dan diameter batang bibit gaharu terhambat. Penambahan unsur hara yang berlebih dapat menekan ketersediaan unsur hara lain yang menyebabkan ketersediaan unsur hara tidak seimbang.

Daun berperan penting dalam pertumbuhan dan perkembangan tanaman karena keberadaan klorofil yang berfungsi sebagai bahan utama fotosintesis. Melalui proses fotosintesis dihasilkan fotosintat yang diangkut oleh pembuluh floem ke seluruh bagian tanaman. Fotosintat ini digunakan tanaman sebagai nutrisi untuk pertumbuhan tanaman (Handayani et al., 2014). Nitrogen yang terkandung dalam asap cair pelepah kelapa sawit berpengaruh pada luas daun kelapa sawit, sebab menghasilkan luas daun yang berbeda nyata dibandingkan kontrol (tanpa pemberian asap cair) (Tabel 3). Nitrogen dapat meningkatkan kuantitas klorofil daun, sehingga proses fotosintesis berlangsung secara optimal dan menghasilkan fotosintat lebih banyak. Hasil fotosintesis juga berguna untuk perkembangan lebar daun (Gardner et al., 1991). Penelitian Nasamsir (2016) menunjukkan pemberian pupuk Vedagro yang mengandung nitrogen dapat 
meningkatkan luas daun bibit kelapa sawit secara nyata.

\section{Diameter Batang}

Hasil analisis menunjukkan bahwa semua perlakuan asap cair pelepah kelapa sawit berpengaruh secara signifikan pada diameter batang bibit kelapa sawit (Tabel 4). Perlakuan asap cair konsentrasi 2\% menunjukan rata-rata diameter batang terbaik yaitu $0,56 \mathrm{~mm}$. Sedangkan perlakuan asap cair konsentrasi $20 \%$ menunjukan diameter batang terendah yaitu $0,33 \mathrm{~mm}$. Namun, hasil diameter batang tersebut tidak berbeda secara signifikan dengan kontrol (tanpa pemberian asap cair pelepah kelapa sawit).

Tabel 4. Diameter batang bibit kelapa sawit (mm)

\begin{tabular}{ccc}
\hline \multirow{2}{*}{ Perlakuan } & \multicolumn{2}{c}{ Pengamatan (MST) } \\
\cline { 2 - 3 } & 4 & 8 \\
\hline P0 & $0,39 \mathrm{a}$ & $0,53^{\mathrm{a}}$ \\
P1 & $0,44^{\mathrm{a}}$ & $0,56^{\mathrm{a}}$ \\
P2 & $0,36^{\mathrm{a}}$ & $0,42^{\mathrm{a}}$ \\
P3 & $0,3^{\mathrm{a}}$ & $0,37^{\mathrm{a}}$ \\
P4 & $0,38^{\mathrm{a}}$ & $0,45^{\mathrm{a}}$ \\
P5 & $0,35^{\mathrm{a}}$ & $0,33^{\mathrm{a}}$ \\
P6 & $0,23^{\mathrm{a}}$ & $0,33^{\mathrm{a}}$ \\
P7 & $0,23^{\mathrm{a}}$ & $0,32^{\mathrm{a}}$ \\
\hline
\end{tabular}

Keterangan: angka pada kolom yang sama diikuti huruf yang sama tidak berbeda nyata merurut uji BNJ 5\%

Asap cair pelepah kelapa sawit mengandung nitrogen dan fosfor yang berperan dalam pertumbuhan diameter batang tanaman. Namun, kandungan hara pada asap cair tersebut diduga tidak mencukupi kebutuhan pertumbuhan diameter batang bibit kelapa sawit. Selain itu juga kemungkinan adaya alokasi fotosintat yang dikirimkan ke bagian paling dibutuhkan pada tanaman. Dimana hasil proses fotosintesis ditransfer melalui jaringan floem ke bagian tanaman yang membutuhkan (Sink) (Snyder dan Carlson, 1983 dalam Yudiwanti et al., 2008). Kemampuan menarik fotosintat berbedabeda tergantung kekuatan dari sink. Kekuatan sink ini bergantung oleh ukuran, aktivitas, kecepatan pertumbuhan, jarak sink terharap unsur hara dan hubungannya dengan jaringan pembuluh (Taiz and Zeiger, 2003 dalam Yudiwanti et al., 2008)
Pada umur bibit kelapa sawit satu hingga dua tahun pertama, fokus pertumbuhan batang terjadi secara horizontal. Kemudian pertumbuhan mengarah ke atas dan pertumbuhan meninggi berlangsung lebih cepat (Mangoensoekardjo \& Semangun, 2008). Hara yang berperan dalam pertumbuhan diameter batang adalah nitrogen, fosfor dan kalium. Menurut Tobing (2018) pada pemberian pupuk $\mathrm{N}$, lilit batang kelapa sawit berkorelasi dengan pertumbuhan jumlah daun pada bibit kelapa sawit varietas Simalungun, PPKS 239 dan Langkat. Semakin besar lilit batang maka semakin besar pula pelepah daun kelapa sawit yang dihasilkan. Lilit batang yang lebih besar menggambarkan besar kecilnya pelepah dan jumlah daun. Sudradjat, Darwis, \& Wachjar (2015) melaporkan pemberian pupuk $\mathrm{N}$ secara kuadratik berpengaruh nyata pada 
jumlah daun dan diameter batang, sedangkan pupuk $\mathrm{P}$ secara linier meningkatkan jumlah daun dan diameter batang bibit kelapa sawit. Hasil yang serupa dilaporkan Halim et al., (2014) kombinasi pupuk nitrogen, fosfor dan kalium mampu meningkatkan tinggi tanaman sebesar 9,5\%, diameter batang $14,4 \%$ dan jumlah pelepah sebesar $4,8 \%$.

\section{KESIMPULAN}

Pemberian asap cair pelepah kelapa sawit berpengaruh nyata pada parameter tinggi tanaman dan luas daun bibit kelapa sawit, akan tetapi parameter jumlah daun dan diameter batang tidak berpengaruh nyata. Perlakuan terbaik berdasarkan parameter tinggi tanaman dan luas daun adalah $2 \%$ asap cair pelepah kelapa sawit.

\section{UCAPAN TERIMA KASIH}

Penelitian ini dapat terlaksana dengan bantuan dan dukungan berbagai pihak. Untuk itu peneliti mengucapkan terima kasih kepada Program Studi Budidaya Tanaman Perkebunan, Politeknik Hasnur dan Perkebunan Inti Rakyat Jelapat Baru yang telah memberikan bantuan dan Kerjasama yang baik.

\section{DAFTAR PUSTAKA}

Fauziati, F., \& Haspiadi, H. (2016). Asap Cair dari Cangkang Sawit sebagai Bahan Baku Industri. Jurnal Riset Teknologi Industri, 9(2), 177-186

Gardner, F. P., Pearce, R. B., \& L, R. M. (1991). Fisiologi Tanaman Budidaya. Jakarta: UI Press.

Gunawan, H., Pustipawati, M. D., \& Sumiasih, I. H. (2019). Pemanfaatan Pupuk Organik Limbah Budidaya Belimbing Tasikmadu Tuban Terhadap Pertumbuhan Dan Hasil Produksi Tanaman Pakcoy (Brassica Rapa L.). Jurnal Bioindustri, 2(1), 413-425.
Gusmailina, G., Komarayati, S., \& Wibisono, H. S. (2018). Pengaruh Arang Dan Asap Cair Terhadap Pertumbuhan Anakan Gyrinops sp. Jurnal Penelitian Hasil Hutan, 36(1),23-31

Haji, A. G. (2013). Komponen Kimia Asap Cair Hasil Pirolisis Limbah Padat Kelapa Sawit. Jurnal Rekayasa Kimia \& Lingkungan, 9(3),109-116

Halim, Sudradjat, \& Hariyadi. (2014). Optimasi dosis nitrogen dan kalium pada bibit kelapa sawit (Elaeis guineensis Jacq.) di pembibitan utama. B.Palma, 15, 86-92.

Handayani, S., Amri, A. I., \& Khoiri, M. A. (2014). Pertumbuhan Tanaman Kelapa Sawit (Elaeis Guineensis Jacq.) Pada Media Campuran Gambut Dengan Effluent Di Pembibitan Utama. Jurnal Online Mahasiswa Fakultas Pertanian Universitas Riau, 1(2).1-11

Istiqomah, I., \& Kusumawati, D. E. (2020). Potensi Asap Cair dari Sekam untuk Meningkatkan Pertumbuhan dan Produksi Padi (Oryza sativa L.). BUANA SAINS, 19(2), 23-30

Lubis, F. ., \& Sjofjan, J. (2016). Pengaruh Pemberian Sludge dan Urin Sapi terhadap Pertumbuhan Bibit Kelapa Sawit (Elaeis guineensis Jacq.) di Pembibitan Utama. JOM Faperta, 3(2), 15-20

Mangoensoekardjo, S., \& Semangun, H. (2008). Manajemen Agrobisnis Kelapa Sawit. Yogyakarta: Gadjah Mada University Press.

Nasamsir, N. (2016). Respon Pertumbuhan Bibit Kelapa Sawit (Elaeis Guineensis Jacq.) Terhadap Aplikasi Pupuk N-P-K (12-0,6-6). Jurnal Media Pertanian, 


$$
1(1), 11-17
$$

Pamungkas, M. A., \& Supijatno, . (2017). Pengaruh Pemupukan Nitrogen Terhadap Tinggi dan Percabangan Tanaman Teh (Camelia Sinensis (L.) O. Kuntze) untuk Pembentukan Bidang Petik. Buletin Agrohorti, 5(2),234-241

Rustam, R., Sulaeman, R., Manurung, G. M. E., \& Kausar. (2012). Pemanfaatan Limbah Kelapa Sawit sebagai Bahan Baku Asap Cair (Cuka Kayu) untuk Meningkatkan Kesejahteraan Petani Kebun Kelapa Sawit. Kementrian Pendidikan Dan Kebudayaan.

Sari, S. G., Selvia, E., Nisa, C., \& Junaidi, A. B. (2020). Pengaruh Pemberian Komposit Kitosan Asap Cair terhadap Pertumbuhan Cabai Rawit Merah Capsicum frutescens Linn. Biotropika: Journal of Tropical Biology, 8(1),8-12

Satria, N., Wardati, \& Khoiri, M. A. (2015). Pengaruh Pemberian Kompos Tandan Kosong Kelapa Sawit dan Pupuk NPK Terhadap Pertumbuhan Bibit Tanaman Gaharu (Aquilaria malaccencis). Jom Faperta, 2(1).1-14

Shaila, G., Tauhid, A., \& Tustiyani, I. (2019). Effect of Urea dose and liquid organic fertilizer humic acid in relation to the growth and yield of sweet corn crop. 35-44.

Shintarika, F., , S., \& , S. (2016). Optimasi Dosis Pupuk Nitrogen dan Fosfor pada Tanaman Kelapa Sawit (Elaeis guineensis Jacq.) Belum Menghasilkan
Umur Satu Tahun. Jurnal Agronomi Indonesia (Indonesian Journal of Agronomy), 43(3),250-256

Sudradjat, Darwis, A., Fauziah, R. R., Ningsih, E. P., \& Sari, V. I. (2015). Optimasi Pupuk Anorganik dan Organik Untuk Meningkatkan Kualitas Bibit Kelapa Sawit (1st ed.). Bogor: IPB Press.

Sudradjat, Darwis, A., \& Wachjar, A. (2015). Optimasi Dosis Pupuk Nitrogen dan Fosfor pada Bibit Kelapa Sawit (Elaeis guineensis Jacq. ) di Pembibitan Utama. Jurnal Agronomi Indonesia (Indonesian Journal of Agronomy), 42(3), 222-227

Sudradjat, \& Siagian, N. A. (2014). Pengaruh Pemupukan Fosfor Dan Kalium Terhadap Pertumbuhan Tanaman Kelapa Sawit (Elaeis Guineensis Jacq.) Di Pembibitan Utama. Agrivigor, 7(2), 105-115.

Tobing, W. L. (2018). Karakteristik Morfofisiologi Varietas Kelapa Sawit Pada Tingkat Pemberian Pupuk N Di Pembibitan Awal.Tesis. Fakultas Pertanian.Universitas Sumatera Utara, Medan.

Yudiwanti, Sudarsono, Purnamawati, H., Yusnita, Hapsoro, D., Hemon, A. F., \& Soenarsih, S. (2008). Perkembangan Pemuliaan Kacang Tanah Di Institut Pertanian Bogor. Seminar Hasil Penelitian Tanaman Kacang-Kacangan Dan Umbi-Umbian, 152-161. 